\title{
Management of the Open Apex using New Biomaterials
}

\author{
${ }^{1}$ Nikita Sarraf, ${ }^{2}$ Jaya Purewal, ${ }^{3}$ Deepak Raisingani, ${ }^{4}$ Ashwini Prasad
}

\begin{abstract}
At the time of root development, trauma or caries results in tooth with immature and open root apices. The single most important factor that affects the success of endodontics is achievement of perfect apical seal. Apexification is done to achieve an apical barrier against which the obturating material can be condensed. Nowadays due to new advancements in materials and methods, single-visit apexification as compared with long and multiple visits (calcium hydroxide apexification) has gained popularity. With the new bioceramic materials like mineral trioxide aggregate (MTA) and Biodentine, perfect seal can be achieved much more easily and effectively. Various treatment modalities are present to treat immature open root apices. Retrograde root end filling by surgical intervention provides faster healing of the associated lesions. Both MTA and Biodentine promise to be quite reliable retrograde filling materials. In the following case reports, apexification using different treatment modalitiesnewer biomaterials-is explained.
\end{abstract}

Keywords: Apexification, Biodentine, Biomaterials, Blunderbuss canal, Immature root apices, Mineral trioxide aggregate, Retrograde filling.

How to cite this article: Sarraf N, Purewal J, Raisingani D, Prasad A. Management of the Open Apex using New Biomaterials. J Oper Dent Endod 2018;3(1):43-47.

Source of support: Nil

Conflict of interest: None

\section{INTRODUCTION}

Pulp necrosis after trauma or caries leads to wide immature or open root apices which have weak dentinal walls with future risk of root fracture if not treated. The age group of 17 to 20 years constitutes the major cases of dental trauma due to falls and accidents. It occurs primarily in maxillary anterior region. ${ }^{1}$

Open apex or incomplete rhizogenesis ${ }^{2}$ refers to the absence of sufficient root development to provide a conical taper to the canal and is referred to as a blunderbuss canal, which means that the canal is wider toward the

${ }^{1}$ Postgraduate Student (3rd Year), ${ }^{2}$ Postgraduate Student (2nd Year), ${ }^{3}$ Head, ${ }^{4}$ Reader

${ }^{1-4}$ Department of Conservative Dentistry and Endodontics Mahatma Gandhi Dental College \& Hospital, Jaipur, Rajasthan India

Corresponding Author: Jaya Purewal, Postgraduate Student (2nd Year), Department of Conservative Dentistry and Endodontics, Mahatma Gandhi Dental College \& Hospital Jaipur, Rajasthan, India, Phone: +919679931719, e-mail: jayaprwl@gmail.com apex than near the cervical area. The management of such cases includes two approaches: Surgical and nonsurgical. Nonsurgical treatment includes conventional root canal therapy done using either roll cone technique without apical barrier or apexification with calcium hydroxide, MTA, or Biodentine followed by obturation either with roll cone technique or with thermoplasticized gutta-percha and revascularization. Surgical intervention includes apicectomy followed by retrograde sealing of the canal with biocompatible material followed by obturation of the canal by conventional methods. The advantages of surgical root end filling are rapidity of the treatment, reducing risk of fracture by reinforcement of dentinal wall, immediate suppression of periapical lesion, and an efficient reliable apical barrier. ${ }^{3}$

The challenges associated with open apex are difficulty in debridement of root canal due to wide apex, lack of apical stop that makes obturation difficult, and thin root canal walls are at risk of fracture. ${ }^{4}$ These problems can be managed by stimulating the formation of a hard tissue barrier at the apex and reinforcing the root against the fracture by a procedure called as apexification. Various materials are used to induce formation of apical barrier, such as calcium hydroxide, resorbable ceramic, freezedried cortical bone and freeze-dried dentin, dentinal shavings, MTA, bone morphogenic protein, and Biodentine. ${ }^{5}$ The use of calcium hydroxide alone or in combination with other drugs was the most widely accepted material for promoting apical barrier formation, until the development of MTA which has the potential for rapid and effective barrier formation. ${ }^{6}$ Biodentine (Septodont, Saint Maur des Fosses, France) is a new calcium silicate-based restorative cement with dentin-like mechanical properties, which can be used as a dentin substitute on crowns and roots similar to how MTA is used., ${ }^{7,8}$

\section{CASE REPORTS}

\section{Case 1}

A 24-year-old male patient was referred to the Department of Conservative Dentistry and Endodontics with chief complaint of discolored upper front tooth since 5 months. Patient gave a history of trauma 6 months back. Clinical examination revealed discoloration in \#21. The electric pulp tester (Denshine Technology Co., Ltd., Hong Kong) revealed nonvital tooth in \#21. Radiographic examination revealed the incomplete and wide open root 

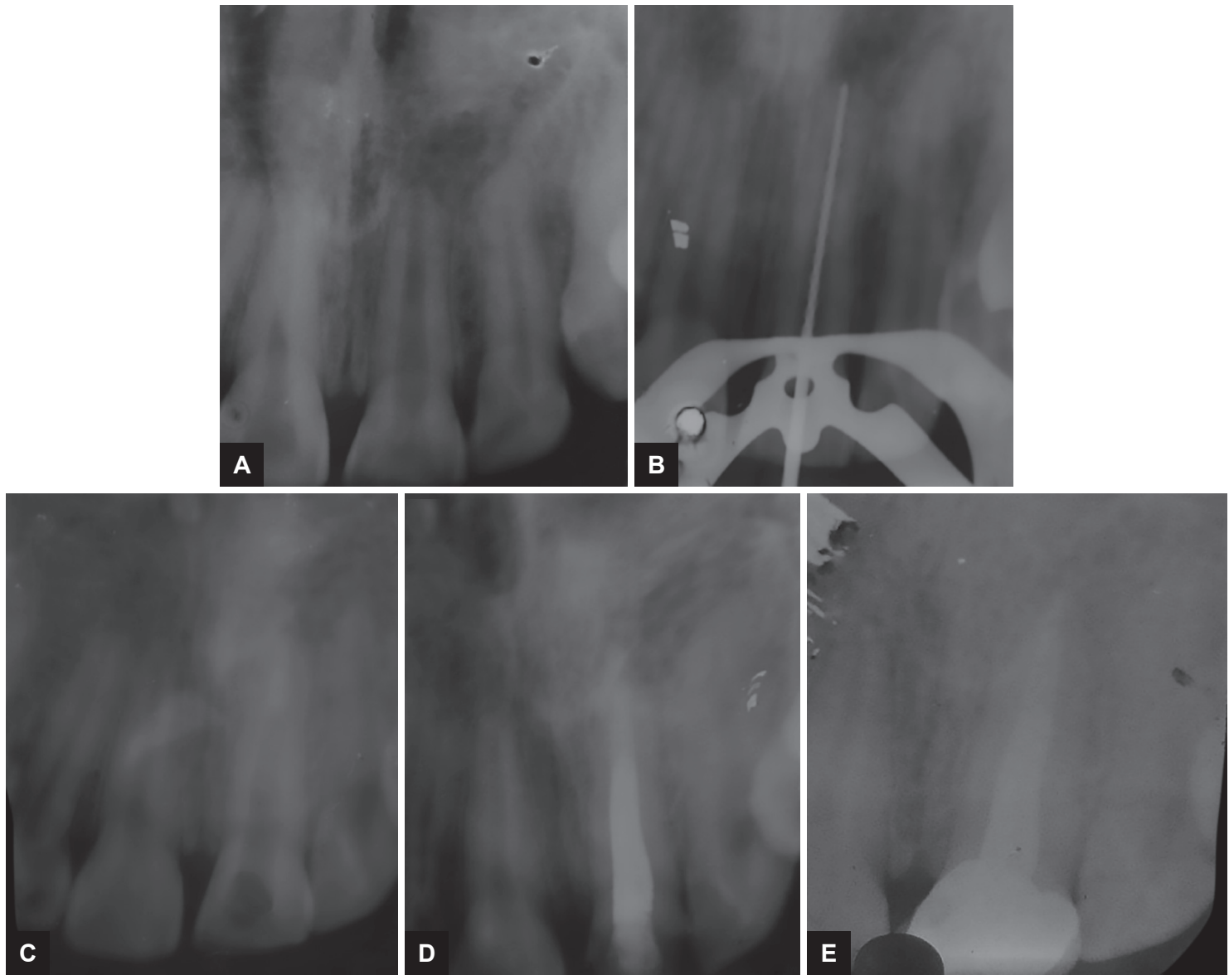

Figs 1A to E: (A) Preoperative radiograph; (B) working length radiograph; (C) apical MTA plug; (D) obturation by roll cone technique; (E) one-year follow-up

apex of the concerned tooth (Fig. 1A). Medical history was noncontributory, and after getting patient's consent, root canal therapy and MTA apexification was planned to be carried out.

Under rubber dam isolation, access cavity was prepared and working length was determined with apex locator (Propex ${ }^{\circledR}$ II, Dentsply, Maillefer, USA) and confirmed by intraoral radiograph (Fig. 1B). Chemomechanical preparation was done with \# 80 hand K files (Dentsply, Maillefer) with copious irrigation using $0.5 \%$ sodium hypochlorite (Parcan, Septodont) and saline (Claris, India) followed by calcium hydroxide (DPI, India) dressing and temporary restoration (Cavit G, 3M ESPE, Germany) for 7 days. In the next appointment, canal was dried using paper points and an apical plug with white MTA (Angelus, Londrina, PR, Brazil) of $3 \mathrm{~mm}$ was formed (Fig. 1C) using MTA carrier (GDC, India) and hand plugger (GDC). Moist cotton pellet was placed over it for 24 hours. The next day, canal was filled by gutta-percha (Dentsply, Maillefer) and $\mathrm{AH}$ plus sealer (Dentsply, Maillefer) by roll c0one technique and the access cavity was sealed with bonded composite (Tetric flow/Tetric Ceram, Ivoclar Vivadent, USA) and full-coverage porcelain-fused-to-metal (PFM) crown was placed over it (Fig. 1D). One year follow up was taken and marked healing was reported (Fig. 1E)

\section{Case 2}

An 18-year-old male patient with chief complaint of pus drainage in anterior front region reported to the Department of Conservative Dentistry and Endodontics. Patient gave history of root canal treatment 2 years back in the same tooth. Medical history was noncontributory. Clinical examination revealed crown in \#12. Radiographic examination revealed endodontically treated tooth with crown and wide open apex in \#12 (Fig. 2A). After getting patient's consent, treatment plan included apexification followed by rehabilitation with fiber post and crown prosthesis.

After rubber dam isolation, gutta-percha from the root canal was retrieved using \#20 H file (Dentsply, Maillefer) (Fig. 2B). Working length was determined with apex locator (Propex ${ }^{\circledR}$ II, Dentsply, Maillefer) and confirmed by intraoral periapical radiograph (IOPA; Fig. 2C). Chemomechanical preparation was done till \#70 K file (Dentsply, Maillefer) along with copious irrigation. Intracanal dressing of calcium hydroxide was given for 7 days. On the subsequent appointment, canal was dried with paper points, and apexification with Biodentine (Septodont) was carried out with the help of MTA carrier (GDC) and a $3 \mathrm{~mm}$ plug was made (Fig. 2D) at the apical root portion. Immediately after that 


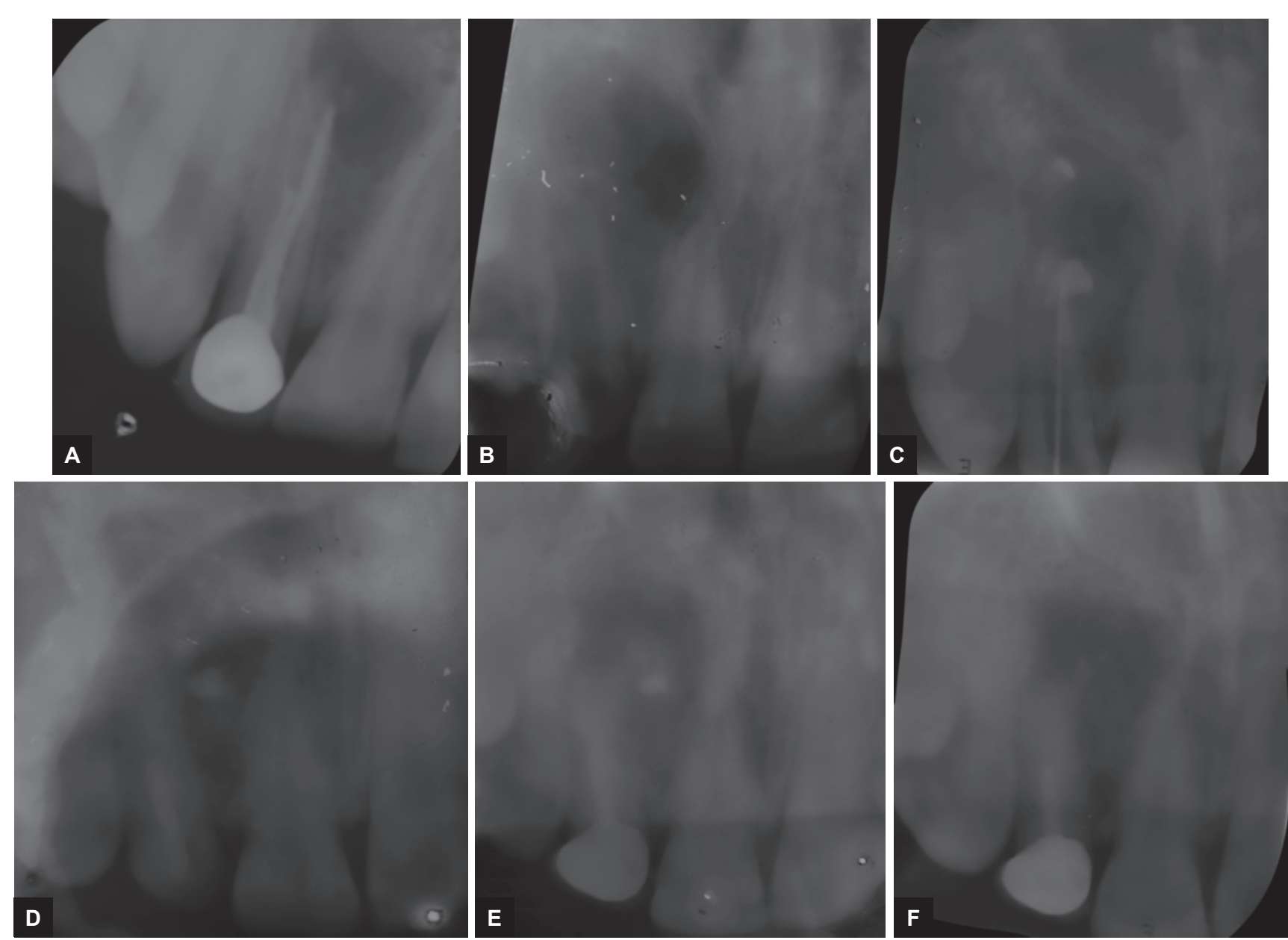

Figs 2A to F: (A) Preoperative radiograph; (B) gutta-percha removed; (C) working length radiograph; (D) biodentine apical plug and light transmitting fiber post; (E) PFM crown cemented; (F) 6-month follow-up

light-transmitting fiber post (Tenax fiber trans, Coltene, USA) was cemented with resin cement (Paracore-dual curing core and resin cement, Coltene) (Fig. 2D). Core was built up using bonded composite (Filtek Bulk Fill, 3M ESPE) and full-coverage PFM crown was cemented (Fig. 2E). Six-month follow-up radiograph shows marked healing of the lesion (Fig. 2F).

\section{Case 3}

A 19-year-old patient came to the Department of Conservative Dentistry and Endodontics with chief complaint of discolored upper front tooth since 3 years. Intraoral examination revealed discolored maxillary right central incisor \#11. Patient's medical history was noncontributory. Radiographic examination revealed open apex \#11 and associated well-circumscribed unilocular radiolucency around the root apex (Fig. 3A). Provisional diagnosis of open apex with periapical abscess was established.

Patient's consent was taken, and access cavity was prepared. Pus drainage was established through the access cavity, working length was determined (Fig. 3B) and thorough irrigation was done using saline, and Metapex (METABIOMED Co., Ltd, Korea) dressing was given twice at 7 days interval. Since there was no relief in pus drainage, surgical management of periapical abscess and open apex followed by retrograde filling was planned. After getting patient's consent, surgical intervention was done in strict aseptic conditions under local anesthesia and antibiotic coverage. After raising the triangular flap (Fig. 3C), the cavity was curetted and apicoectomy was done (Fig. 3D). After achieving hemostasis retrograde, MTAplug was made using MTA carrier and hand plugger (GDC). Flap was sutured using 3-0 Mersilk (Fig. 3E). At 1-week follow-up, MTA plug was evaluated by IOPA (Fig. 3F) and sutures were removed (Fig. 3G). Obturation with gutta-percha and sealer was done by roll cone technique and immediate IOPA was taken (Fig. $3 \mathrm{H}$ ). Since patient had crowding in upper and lower teeth, patient was referred to orthodontic department.

\section{DISCUSSION}

Apexogenesis is defines as "A vital pulp therapy procedure performed to encourage continued physiological development and formation of the root end; frequently used to describe vital pulp therapy performed to encourage the continuation of this process. ${ }^{9}$ 

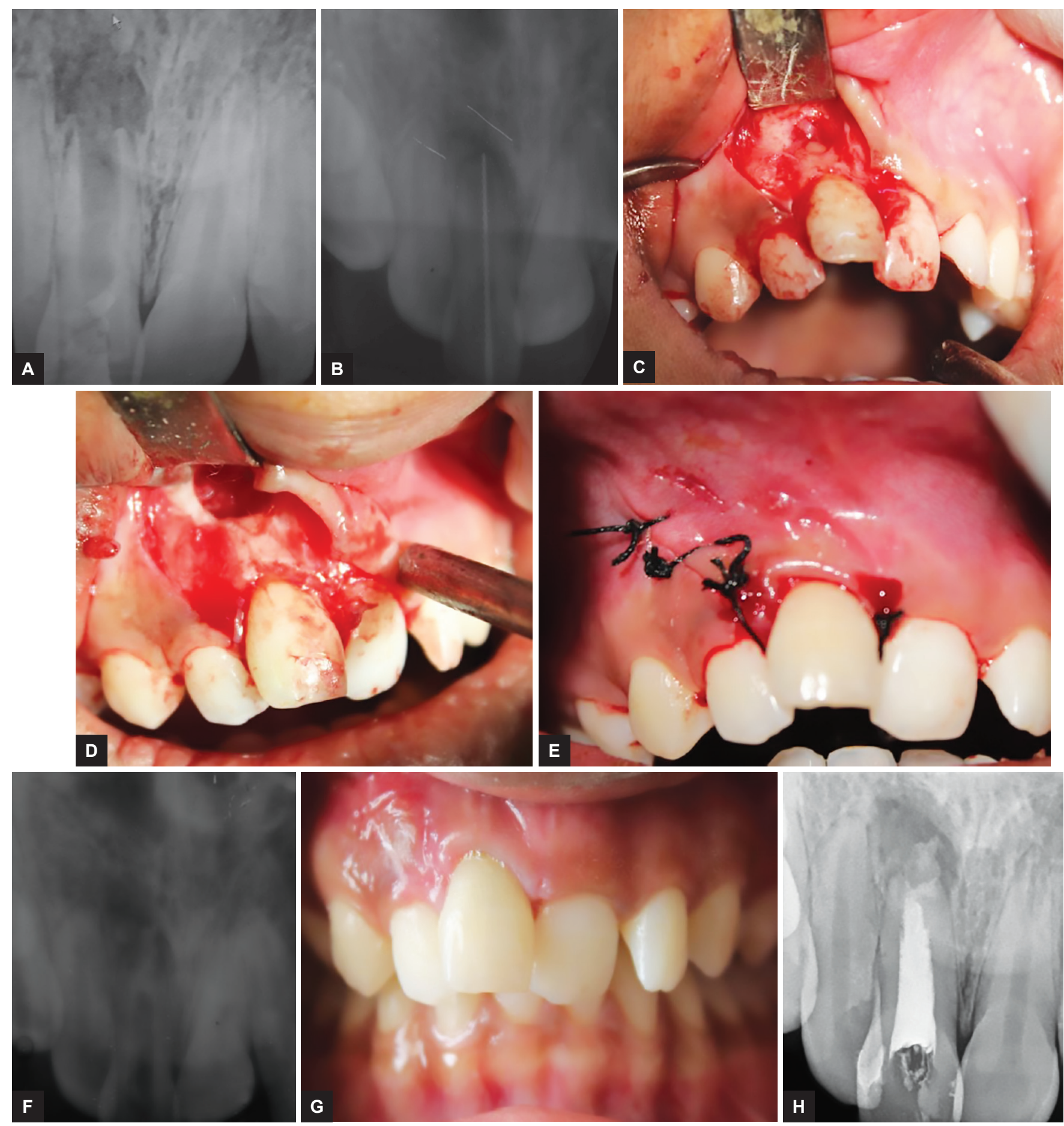

Figs 3A to H: (A) Preoperative radiograph; (B) working length radiograph; (C) exposed lesion by reflecting flap; (D) apicoectomy and curettage of the lesion; (E) suturing the flap; (F) MTA plug; (G) 1-week follow-up; $(H)$ obturation by roll cone technique

Apexification is defined as "a method to induce a calcified barrier in a root with an open apex or the continued apical development of an incomplete root in teeth with necrotic pulp." ${ }^{\prime 9}$

Although there is good success rate of apical barrier formation using calcium hydroxide, but patient's compliance is required for follow-up. Apexification using MTA and Biodentine is an alternative treatment modality in immature pulpless teeth. ${ }^{11}$ With the discovery of MTA by Parirokh and Torabinejad, ${ }^{10}$ it has now become the material of choice for apexification. Mineral trioxide aggregate has a wide range of advantages which could be exploited, such as biocompatibility, ${ }_{1}^{11-15}$ hard tissue formation, sealing ability, ${ }^{9}$ and its antibacterial property. ${ }^{13}$ Long setting time of ProRoot MTA is a major shortcoming of the material, apart from other disadvantages like difficult handling characteristics, discoloration potential (gray MTA), low washout resistance, and high material cost. ${ }^{16,17}$.

Apexification with Biodentine requires significantly less time. ${ }^{18}$ Leiendecker et $a{ }^{19}$ in their study compared 
the microleakage of glass ionomer cement, MTA, and Biodentine $^{\mathrm{TM}}$ when used as a retrograde filling material and concluded that Biodentine ${ }^{\mathrm{TM}}$ exhibited the least microleakage when compared with other materials. ${ }^{19}$ In a study conducted by Sulthan et al, evaluation of the $\mathrm{pH}$ and calcium ion release of MTA and Biodentine ${ }^{\mathrm{TM}}$ when used as root end fillings was done. They concluded that Biodentine $^{\mathrm{TM}}$ presented alkaline $\mathrm{pH}$ and ability to release calcium ions similar to that of MTA. ${ }^{20-22}$

Achievement of a perfect seal at the apex using an inert filling material is the single most factor affecting success in endodontics. As an endodontist, we should be careful to adopt the best available evidence for supporting clinical treatment plans. Ignoring science for the sake of speed and simplicity may place the final outcome for our patients in jeopardy.

\section{CONCLUSION}

There have been changes in the rationale governing the treatment of teeth with open apex during the last 20 years. Recent materials, such as MTA and Biodentine are promising materials and play important role in healing and sealing of root canal and thus saving patients from psychological trauma of surgical procedures. ${ }^{21}$

\section{REFERENCES}

1. Andreason JO, Raven JJ. Epidemiology of traumatic dental injuries to primary and permanent teeth in a Danish population sample. Int J Oral Surg 1972;1(5):235-239.

2. Andreason JO, Andreason FM. Essentials of trau,atic injuries to the teeth 2nd ed. Copenhagen: Munksgaard, 2000. p. 188

3. Grech L, Mallia B, Camilleri J. Characterization of set Intermediate Restorative Material, Biodentine, Bioaggregate and a prototype calcium silicate cement for use as root-end filling materials. Int Endod J 2013 Jul;46(7):632-641.

4. Kvinnsland SR, Bårdsen A, Fristad I. Apexogenesis after initial root canal treatment of an immature maxillary incisor-a case report. Int Endod J 2010 Jan;43(1);76-83.

5. Cvek M. Prognosis of luxated non-vital maxillary incisors treated with calcium hydroxide and filled with gutta-percha: a retrospective study. Endod Dent Traumatol 1992 Apr;8(2):45-55.

6. Enkel B, Dupas C,Armengol V, Akpe Adou J, Bosco J, Daculsi G, Jean A, Laboux O, LeGeros RZ, Weiss P. Bioactive materials in endodontics. Expert Rev Med Devices 2008 Jul;5(4):475-494.

7. Moretton TR, Brown CE Jr, Legan JJ, Kafrawy AH. Tissue reactions after subcutaneous and intraosseous implantation of mineral trioxide aggregate and ethoxybenzoic acid cement. J Biomed Mater Res 2000 Dec;52(3):528-533.
8. Laurent P, Camps J, About I. Biodentine (TM) induces TGF- $\beta 1$ release from human pulp cells and early dental pulp mineralization. Int Endod J 2012 May;45(5):439-448.

9. American Association of Endodontics. Glossary of endodontic terms. Chicago (IL): American Association of Endodontics; 2016.

10. Parirokh M, Torabinejad M. Mineral trioxide aggregate: a comprehensive literature review-part I: chemical, physical, and antibacterial properties. J Endod 2010 Jan;36(1):16-27.

11. Zanini M, Sautier JM, Berdal A, Simon S. Biodentine induces immortalized murine pulp cell differentiation into odontoblast-like cells and stimulates biomineralization. J Endod 2012 Sep;38(9):1220-1226.

12. Torabinejad M, Watson TF, Pitt Ford TR. Sealing ability of a mineral trioxide aggregate when used as a root end filling material. J Endod 1993 Dec;19(12):591-595.

13. Torabinejad M, Hong CU, Pitt Ford TR, Kaiyawasam SP. Tissue reaction to implanted super-EBA and mineral trioxide aggregate in the mandible of guinea pigs: a preliminary report. J Endod 1995 Nov;21(11):569-571.

14. Torabinejad M, Pitt Ford TR, Abedi HR, Tang HM. Tibia and mandible reactions to implanted root-end filling materials (abstract 56). J Endod 1997;23:263.

15. Torabinejad M, Ford TR, Abedi HR, Kariyawasam SP, Tang HM. Tissue reaction to implanted root-end filling materials in the tibia and mandible of guinea pigs. J Endod 1998 Jul;24(7):468-471.

16. Torabinejad M, Hong CU, Pitt Ford TR, Kettering JD. Cytotoxicity of four root end filling materials. J Endod 1995 Oct;21(10):489-492.

17. Torabinejad M, Hong CU, Pitt Ford TR, Kettering JD. Antibacterial effects of some root end filling materials. J Endod 1995 Aug;21(8):403-406.

18. Kokate SR, Pawar AM. An in vitro comparative stereomicroscopic evaluation of marginal seal between MTA, glass inomer cement and biodentine as root end filling materials using 1\% methylene blue as tracer. Endodontology 2012 Dec;2: 36-42.

19. Leiendecker AP, Qi YP, Sawyer AN, Niu LN, Agee KA, Loushine RJ, Weller RN, Pashley DH, Tay FR. Effects of calcium silicate-based materials on collagen matrix integrity of mineralized dentin. J Endod 2012 Jun;38(6):829-833.

20. Parirokh M, Torabinejad M. Mineral trioxide aggregate: a comprehensive literature review-part III: clinical applications, drawbacks, and mechanism of action. J Endod 2010 Mar;36(3):400-413.

21. Sulthan IR, Ramchandran A, Deepalakshmi A, Kumarapan SK. Evaluation of $\mathrm{pH}$ and calcium ion release of mineral trioxide aggregate and a new root-end filling material. E J Dent 2012;2(2):166-169.

22. Wongkornchaowalit N, Lertchirakarn V. Setting time and flowability of accelerated Portland cement mixed with polycarboxylate superplasticizer. J Endod 2011 Mar;37(3): 387-389. 